\title{
The Various Aspects Of Naga Art
}

\author{
Iris Odyuo \\ Associate Professor, Department of History, Sao Chang, College, Tuensang, (Nagaland), India
}

\begin{abstract}
The research study is an attempt to analyze the various aspects of Naga art. Why and how such practices like the feasts of merit and headhunting exist and visual forms such as the colorful textiles, woodcarving, body tattooing, weapons and ornaments produced. Among the Nagas, art and rituals are interdependent; none of them complete without the other. Everyday activities like work in the fields, hunting, fishing, birth and dead, followed minute taboos and observances. Among the Nagas adherence to the prescribed rituals and taboos was strictly observed in their art, any deviations from the technical tradition were believed to bring ill-fortune such as death, famine, sickness or defeat in war. With very limited tools at their disposal, the Naga artisan skillfully reproduced traditional styles by simply visualizing the forms and lines mentally.
\end{abstract}

Keywords - feasts of merit, headhunting, morung (men's ceremonial house), rituals, taboos

\section{Introduction}

Nagas are an indigenous people, with their homeland stretching along the north eastern states of Indian States of Nagaland, Assam, Manipur, Arunachal Pradesh and north western Myanmar (Burma). The Nagas on the Myanmar side lies within the Sagaing state. The state of Nagaland was created out of the Naga Hill areas of Assam and North Eastern Frontier Agency (NEFA) in 1963 becoming the $16^{\text {th }}$ state of the Indian Union. Spread over an area of 16,579 square kilometers, the population of the Nagas in India is about four million, out of which 71.03 per cent of the population resides in rural areas and 28.97 per cent in urban areas as per 2011 census.

The Nagas belong to multi-ethnic groups and subgroups, though they have no common language, they have similar cultures and traditions. The 16 major tribes such as the Angami, Ao, Sema, Lotha, Rengma Chakhesang, Khiamniungan, Chang, Konyak, Phom, Sangtam, Liangmei, Yimchungrü, Pochury, Rongmei and Zeme and numerous sub-tribes each with its own distinct languages, custom and dress inhibit the 11 districts of Kohima, Dimapur, Mokokchung, Wokha, Zunheboto, Longleng, Kiphiri, Tuensang, Mon, Peren and Phek with Kohima as its capital. Tribes such as the Khiamniungan, Konyak, Yimchungrü, Tikhir, Makuri and Tangkhul have villages on either side of the international border.

One of the important aspects of Naga art is how rituals for various occasions are closely connected to different forms of art. Art and ritual beliefs among the Nagas are interdependent, none of them complete without the other. Everyday activities like work in the fields, hunting, fishing, birth and dead, followed minute taboos and observances. Among the Nagas adherence to the prescribed rituals and taboos was strictly observed in their art, any deviations from the technical tradition were believed to bring ill-fortune such as death, famine, sickness or defeat in war. With very limited tools at their disposal, the Naga woodcarver skillfully reproduced traditional styles by simply visualizing the forms and lines mentally.

Traditional Naga religion recognizes a supreme God or Creator and lesser gods such as the spirits of the rivers, forest, mountains, caves and stones. Nagas believed that proper sacrifices and appeasement must be made to them for their blessings for good crops, protection from natural disaster and unforeseen calamities. For example, accidental deaths were attributed by the Nagas as having incurred the disfavor of their gods. But when proper sacrifices are made and rituals observed, a man is blessed with healthy children, success in war, bountiful harvest and increase in livestock which enables him to perform the feasts of merit and thereby gains the right to wear the much coveted warrior and feasts giver's cloths, ornaments and house decorations, status and recognition for himself and blessings for the whole village.

\section{Brief Literature Review}

Until the advent of the British in the 1830s, the Nagas had little contact with the outside world apart from cultural contact with the Ahoms, who ruled Assam from the $13^{\text {th }}$ to early $19^{\text {th }}$ century. Lotha (2007) writes that Naga Anthropology developed parallel to the growth of the British Empire in the Naga Hills. Beginning from the mid 1830s various articles in the form of military and survey reports and classical monographs were written on the Naga tribes such as the Angami, Sema, Lotha, Ao, Konyak and Rengma Nagas by Anthropologist, British administrators, Surveyors and Christian missionaries, but writings about Naga art are 
meager. Frances Jenkin's reports published in Pemberton's Report on the Eastern Frontier on British India (1835), and Moffat Mills's Report on the Province of Assam (1854), and John Butler's Travels and Adventures (1855), E.T. Dalton's Descriptive Ethnology of Bengal (1872), had brief descriptions about the habitat, physic, headhunting, agriculture, implements, dress, warfare, crime and punishment, marriage, weapons and so on. Lotha (2007) writes, in 1901 the Government of India took up the suggestion of the British Association for Advancement of Science and funded the ethnographic Survey of India to be carried out all over India in connection with the census operations. The outcome of the ethnographic survey was the publication of various monographs- T. C. Hodson, Naga Tribes of Manipur (1911), J.P. Hutton, Angami Nagas (1921), Sema Nagas (1921) J.P. Mills, The Lotha Nagas (1922), The Ao Nagas (1926), and The Rengma Nagas in 1937. Henry Balfour also wrote articles on different topics about the Nagas $(1914,1917,1923,1926)$ and Christopher von Fürer-Haimendorf wrote Naked Nagas (1939), and many articles on the Konyak Nagas (1938a, 1938b, 1939, 1943). On the subject of Naga art such as woodcarvings, basketry, textiles, pottery and metalworks these monographs describes the techniques and modes of production but fail to give importance to the artists or artisans who made such arts possible. Robert Gosset Woodthorpe's The Lushai Expedition (1873), and the descriptions of land surveys, research and observations in the Naga hills collected in the Narrative Reports (1876-1878) and the Notes on the Wild Tribes Inhabiting the So-Called Naga Hills (1882) has illustrations of Naga village scene, burial ground, woodcarvings, ornaments, body tattoo, weapons, clothing and tools. These visual representation is a "testament to long-forgotten local cultures and will endure as early examples of the visual ethnography of that region" (Michael Oppitz 2008:33). The photographs taken by Christoph von FürerHaimendorf in the Naga Hills in 1935 and 1937 constitutes one of the finest photographs on the Nagas regarding their agriculture, ritual and art and used extensively by Julian Jacobs in his book The Nagas: Hill Peoples of North East India (1990). Anthropological museum collections in Europe of artifacts such as ornaments, headdresses, weapons, hunting equipments, baskets, musical instruments, textiles, looms, spinning equipment, as well as pipes and toys collected by Adolf Bastian (1878-79), Lucian Scherman (1910-11), Hans-Eberhard Kauffmann (1936-37), Paul Wirz (1938) and Milada Ganguli (1963- 92), Henry Balfour (1922-23), John Butler (1869-75), Ursula Graham Bower (1937-46), James Henry Hutton (1909-35) and James Philip Mills (1916-38), Charles Pawsey (1920-48), R.G. Woodthrope (1875-76), Christoph von Fürer-Haimendorf (1936-37) among others, give us great insight into the minds of the creative Naga artisans. Verrier Elwin`s The Art of the North East Frontier of India (1959) and Milada Ganguly`s Naga Art (1993) describe Naga art in general. Oppitz et al, Naga Identities: Changing Local Cultures in the Northeast of India (2008) and also J.D. Saul's The Nagas of Burma: Their Festivals, Customs and Way of Life (2005) show the continuing Naga artistic tradition in the Nagaland and Burma. Aglaja Stirn and Peter van Ham's The Hidden World of the Nagas (2003) and Vibha Joshi and Aditya Arya`s The Land of the Nagas (2004), Richard Kunz, Vibha Joshi (eds), Naga- A Forgotten Mountain Region Rediscovered (2008), and Renchen Women Welfare Society's Lotha Naga Textiles and Patterns (2010) contain some photographs of Naga Art.

Among Naga scholars M. Alemchiba Ao's Arts and Crafts of Nagaland (1968) was the first to comment at length on the artistic activities of the Nagas. The monograph describes the technical processes involved in the working of the Naga crafts such as spinning and weaving textiles, pottery, woodcarving, basketry and metal works. Ao, admits being a Naga himself, he had certain initial advantages in the field investigation and in the processes of analyzing the data. But at the same time, he states: "it was not easy to carry on such an investigation in a land where the people suffered from the effects of hostility continuously for a decade. Added to this was the divergence of Naga traditions" (1968: ix). Panger Imchen in his book Ancient Ao Naga Religion and Culture: A Foundation towards Christianity (1993) he has used the sociological and anthropological methods and interpretations about the ancient Ao Naga religion, cultural practices and beliefs in the context of Christianity and change. Kajen Mongro's Naga Cultural Attires and Musical Instruments (1999) gives detailed description and the various names, meanings, utility and social functions of Naga ornaments, textile and musical instruments. N. Venuh's Naga Society: Continuity and Change (2004) explores the various aspects of Naga culture, customs, traditions and social changes that are taking place in the Naga society today with special reference to change and continuity in Naga customary law, festivals, dress, the morung system, beliefs and practices, political institutions, Naga worldview and transformations. Abraham Lotha's History of Naga Anthropology 1832-1947 (2007) examines the relationship between anthropology and colonial administration in the development of Naga anthropology. Some of his important writings on Naga art include Understanding Naga Woodcarving (1998), and Naga Woodcarving Heritage: Carving the Present and the Future (2007) here he critically analyze non-utilitarian woodcarvings in the traditional Naga society. He writes that ethnic arts can be appreciated better when one understands the cultural context of the art. Description of the socio-cultural settings that inspired the non utilitarian woodcarvings, the meanings and significance on non utilitarian woodcarving in the Naga society are dealt with in this paper, while Naga Warfare (1998) discusses the causes for warfare in the Naga society and how headhunting came to be institutionalized. 


\section{Methodology}

The research methodology for the study is mostly drawn from participant observation, formal and informal interviews, recording life histories of individual artisans and narrative or reflexive method and photography. Data collected through fieldwork illustrate the daily life of the Naga artisans and the stories surrounding their arts. To supplement the information collected through these means, the materials the researcher consulted include archival resources from libraries, unpublished articles and seminar research papers and published chapters, essay and reviews in journals and newspapers on ethnic art.

\section{V. Agriculture}

Every aspect of Naga life is interconnected with agriculture and its rituals, ceremonies and festivals. Nagas perform a series of agricultural ceremonies to appease the spirits of the forest, rivers, rocks and the fields to protect the crops and to increase agricultural yield. Specific rituals was observed for each agricultural activity such as the selection of sites for cultivation, clearing of the land of trees and undergrowth, the burning of the felled trees and bushes, the first sowing of seeds and the first harvesting of crops. Agriculture is supplemented by craft making especially in sowing and harvesting seasons. The relationship between agriculture and craft production is insep arable.

In order to perform the various agricultural rituals and ceremonies, specific baskets are needed. For example, a ceremonial basket which the Khiamniungan Naga called mao was also used to forecast the first rice seeds. Before rice was transplanted, the Chang Nagas invited elder clan members to pray for a good harvest and they were served food in a ceremonial rice plate referred to as lah phaou. Another important basket used by Khiamnuingan Nagas, is the rice beer cup hanger or ting pa chang, a conical basket cover which looks like a lamp shade made of thin slices of the inner part of a bamboo stitched together with cane thread. It is hung on the beam called ling le shio (seed decorated place) near the hearth. Hooks made from the stump of side branches of a tree is suspended inside the ting pa chang. On the hooks are hang the amlak tso (gourd beaker) which contains a pinch of salt, a river fish, and a small token of millet biscuit called lak pou which is replaced on every important agricultural festivals, new house construction or repair and feast giving ceremonies. It is never thrown as it is believed to contain the blessings of the household. On the hooks are also hung the house owner's rice beer cups and baskets containing seeds for the next sowing and animal heads killed for the ritual ceremonies.

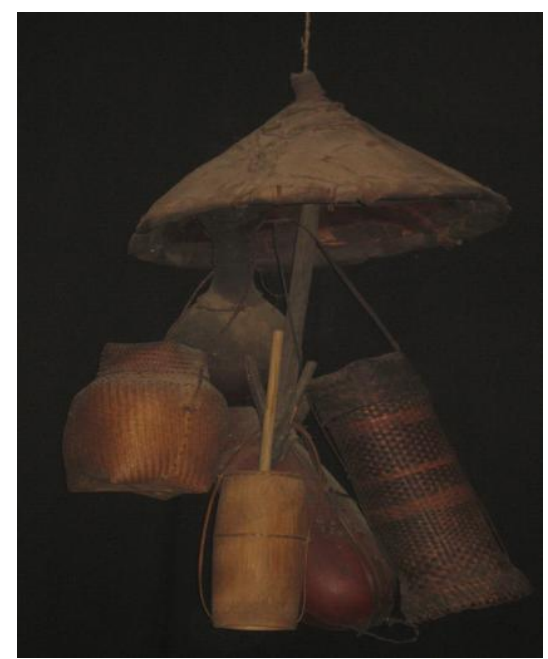

Fig.1 Rice beer hanger called ting pa chang by Khiamniungan Nagas is a conical basket cover made of thin slices of the inner part of a bamboo stitched together with cane thread. It is hung on a beam near the hearth, Lengnyu village, 2010

\section{Feasts of merit}

Another aspect of Naga art is the feasts of merit. The social status of the Nagas depends largely on the ability of an individual to provide feasts. The performance of these series of feasts was optional but the continual quest for prestige in the Naga society encouraged and at the same time provided every married man, an equal opportunity to compete for status through the feasts of merit. The prestige of an individual was closely bound up with expenditure and public display of wealth. The number of feasts varied from tribe to tribe and hosting of this kind of communal feasts was always an expensive affair, necessitating lavish supply of cattle and rice beer, and each series in the feasts of merit becoming more elaborate and costly than the last one performed. Every Nagas hoped to perform the whole series in the feasts of merit and gain honor both in life and after death. 
At the same time, these ritual feasts of merit demanded not only the intensification of economic production such as rice and grains, breeding of pigs, mithun and fowls but ceremonies also ensure that the wealthy individual shares and redistributes his accumulated wealth with his fellow villagers who are less fortunate thereby creating a balance in the society.

\section{V1. Headhunting}

Another important aspect of Naga art is headhunting. Headhunting was once an institutionalized cultural practice among all the Naga tribes which has social and religious sanction. A Naga method of fighting and headhunting was a combination of individual enterprise and teamwork. Individual bravery was greatly admired and each warrior sought to distinguish himself by taking as many heads as possible. Every Naga aspired to take an enemy's head and flaunt his bravery for it not only brought him prestige, honor and entitlement to wear the much coveted warrior's paraphernalia but in killing an enemy he was doing good for the village, in fact for the survival of the village.

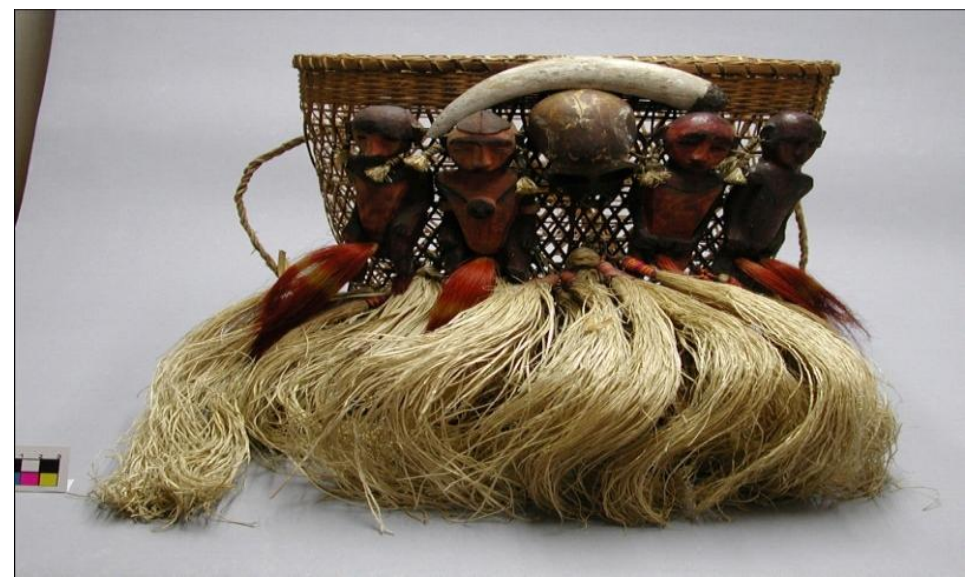

Fig.2 Hip basket called dangsa richly decorated with carved wooden human head, monkey skulls, boars' tusks and cane balls to indicate the warrior status.

\section{V11. The Morung}

The first step towards building of a new village was to select the central location to construct the morung (Men's ceremonial house) Naga villages are divided into khels (wards) and each khel has a morung. The morung was the most important social, political and religious component of the village. The numbers and size of morung in a village depend on its population and the vitality of the clan member who construct it. The morung was the centre of social and cultural life of the Nagas and had no individual existence apart from the community. It functioned as the guard-house and armory, recreation club, center of education, art and discipline. It was here where debates and discussions concerning the interests of the clan and village and economic and political rituals were held and the art of warfare, and skills such as woodcarving, basketmaking, songs, dances and folklore of the tribe was communicated orally from generation to generation. The morung often housed the log-drum considered as sacred by the men for it was not only used as a signaling instrument but the heads of enemies were kept or hung displaying the men's dominance in warfare - strictly a male prerogatives.

Among the Nagas, woodcarving communicated the value systems example, of the tribes. The carvings of human figures and animals represent their characters and not their magical or spiritual powers. For instance, the carvings of animals such as the tiger, mithun (Bos frontalis) hornbill, python and elephants in the morung, are believed to make the morung members brave and wealthy and at the same time, create terror and panic among the enemies. The tree from which the main post, the side-beams, the ridge-pole of the morung and the log-drum was felled had to be strong, straight and tall without any blemish; so too the men of the village had to be just and honorable. The main morung post communicated the value of honorableness; carvings of tiger, elephant and human heads communicated men's strength and aggressiveness in warfare; while that of the mithun and python wealth and the hornbill beauty.

Using simple tools and materials that reflected their environment - wood, bamboo, stones, clay, iron, bones, tusk, cotton, nettle and bark fibers, natural dyes and even feathers into their art, the practice of headhunting and feasts of merit and the morung system stimulated many artistic productions such as colorful textiles, woodcarvings, ornaments, weapons, body tattoos, songs and dances. 


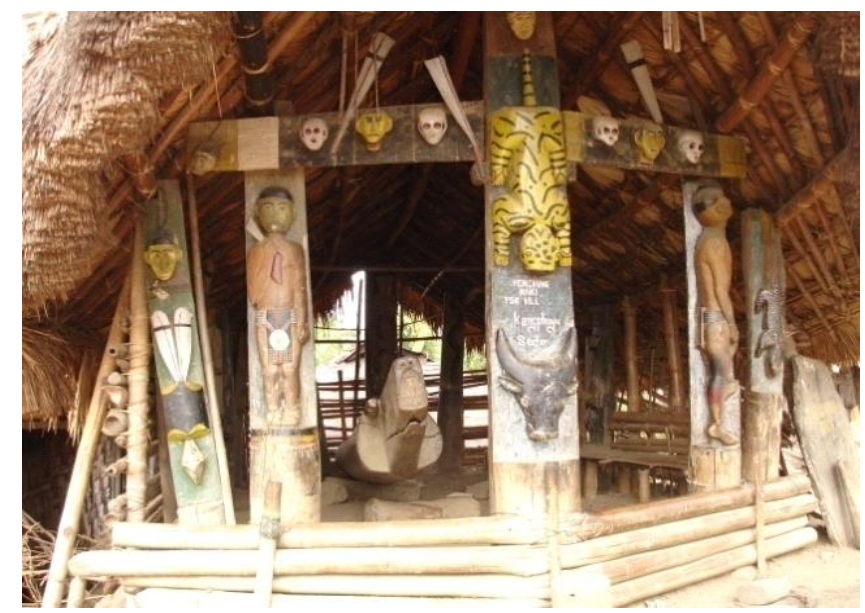

Fig. 3 Carvings of human figures, mithun head, hornbill and tiger in front of the Lomou morung at Tuensang village, 2011

\section{V111. Textiles}

Among the Nagas it was not only the social identity of the weaver which added values and meaning in the cloth but the rareness of the materials, the amount of labour invested in their production and the symbolic meanings of the design motifs. The most prominent colour for warrior's cloth is red. Red signifies enemies' blood and therefore bravery. Another prominent colour frequently used is black as a background or in combination with other colours such as green, orange, yellow and blue. Many of the skills needed for collecting and extracting natural dyes such as dark blue colour from indigo, red from a tree which the Chang Naga called lungpai, the bark of which is crushed with the twigs of a wild creeper called wailou and weaving the various intricate designs required time and patience and a nice coordination of hand and eye. Goat's and dog's hair dyed red and black, beetle wings, bird feathers, yellow orchid stem, cowrie shells and glass beads were rare and precious. And it was stitched on or woven into the cloth worn by warriors and wealthy individuals.

The most crucial role for textiles for the Nagas was in identifying the gender, social status and specific regional locations of the wearer. For example, among the Lotha Nagas ordinary man at Yikhim, Changsü and Riphyin villages wore a plain white cotton cloth called Sünli. (Renchen Women Welfare Society 2010). The yarn used for these plain weave cloths were cotton, nettle fibre and wild jute which was sometimes dyed dark blue with indigo. Circles of cowry shells sewn to the surface of a basic black shawl are common to the central and eastern Naga tribes such as the Ao, Chang, Khiamniungan Sangtam, Sema, Phom and Yimchungrü. This shawl is six foot long by four foot wide and has 53 rectangular red designs, each measuring about four centimeters long by three and half centimeters wide on a black background; circles of cowry shells are stitched on to the shawl. Sometimes outline of the human figure and the V-shaped chest tattoo are added indicating the martial achievements of the wearer. In addition to cowry shells, tassels on shawls with red or black dyed dog's or goat's hair, yellow orchid stem and beetle wings, announced the wealth of the wearer.

Feasting the village cannot take place without the cooperation and contribution of the wife who not only did the bulk of agricultural work but she also has to pound the rice and brew the beer for the feast and weave the ceremonial shawl. For her contribution she acquires the right to share in the high status gained by her husband. Wives and daughters of Sangtam Naga can wear a shawl with diamond shaped patterns symbolizing the grains of rice used in feasting the villagers and also the X-shaped pattern symbolizing the pounding mortar and pestle for the rice pounded to make rice beer.

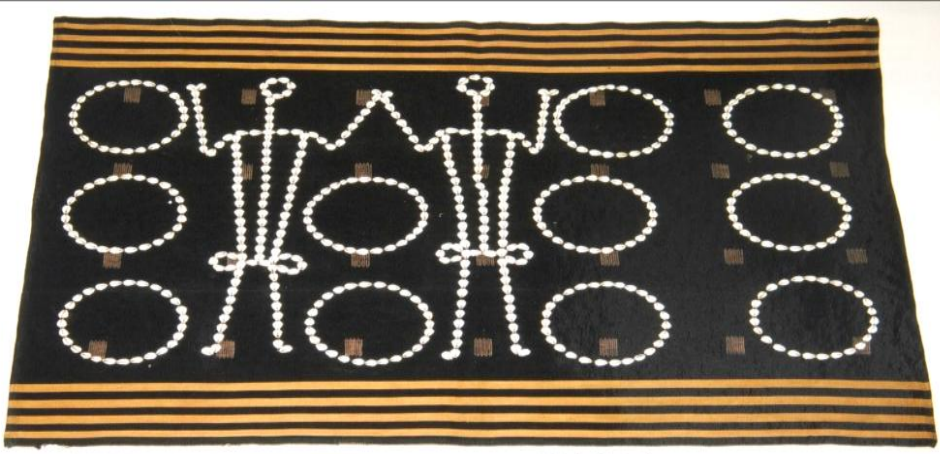

Fig.4 Circles of cowry shells sewn to the surface of a black shawl and outline of human figure indicating the martial achievements of the wearer. 


\section{X. Ornaments}

Nagas are closely related to their environment and natural materials like bamboo, cane, orchid stems, stone, glass, red dyed goat's hair, claws, bones, teeth, horns, sea-shell beads, white Job's tears, natural dyes, feathers and even beetle wings found their way into their ornaments. Some ornaments can be worn by anyone, but most ornaments have particular meaning and they are therefore 'powerful' (Jacobs 1990:103), and the right to wear them is strictly controlled. The tiger's tooth, claws and the boar's tusk are considered to be of high value and the owner of it is formidable, respected and feared. Apart from the husband, the wife also gains the right to wear certain ornaments. Hornbill feathers are also worn by wives and daughters of man who had done the mithun sacrifice and among the Konyak the daughter of a warrior chief can wear the feather on her headdress.

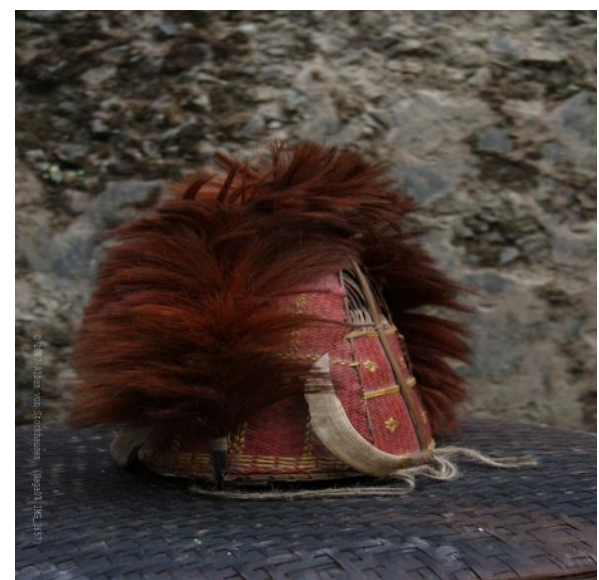

Fig.5 a conical ceremonial headgear made of bichromatic weave done in red dyed cane with yellow orchid stem and red dyed goat's hair, Tuensang, 2007

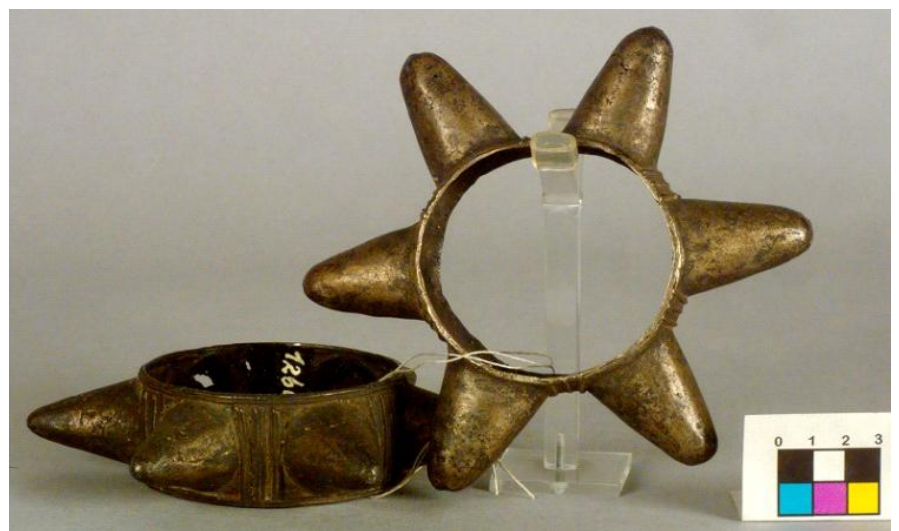

Fig.6 Khiamniungan warrior of note wears a spike brass armband called khiaptso.

\section{Weapons}

In a war within khels the Khiamniungans like the Tangkhuls and the Lothas were restricted from using actual daos and spears. They were allowed to use wooden sword or club for hand to hand combat, a sturdy cane helmet with the inside cushioned with nettle fiber cloth to protect the head, a bamboo shield, arm- guard and leg- guard to fend off blows to the body. Successful warriors could decorate their dao (a kind of long knife) handle and dao holder, and the spear with red dyed cane and goat's hair and yellow orchid stem. The shields used in war were usually made of buffalo, rhinoceros or elephant hide. Angami warriors shields of cane matting are decorated with red dyed goat's hair and vertical line of human heads made of bear skin. Sometimes the shields were covered with leopard, bear and tiger skin. Even drinking cups, smoking pipes, panji (bamboo splint) basket of warriors were elaborately decorated. The Konyak in addition to incised and carved wooden and bone hairpins, brass and wooden representations of human heads worn as chest ornaments, carries a hip basket known as (dangsa), richly decorated with carved wooden human head, monkey skulls, boars' tusks and cane balls to indicate the warrior status. 


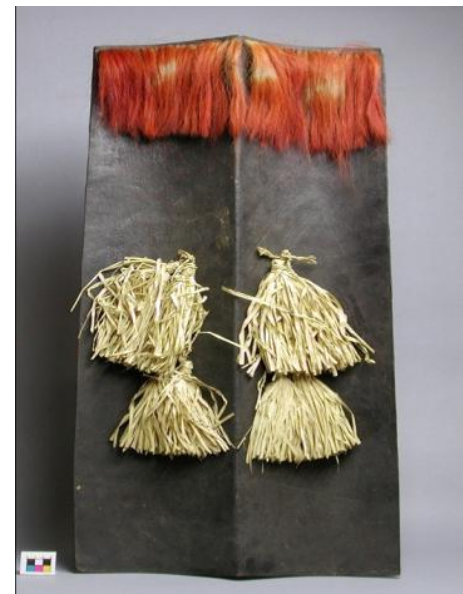

Fig.7 Warrior's shield made of buffalo; rhinoceros or elephant hide and decorated with grass tassels and red dyed goat's hair.

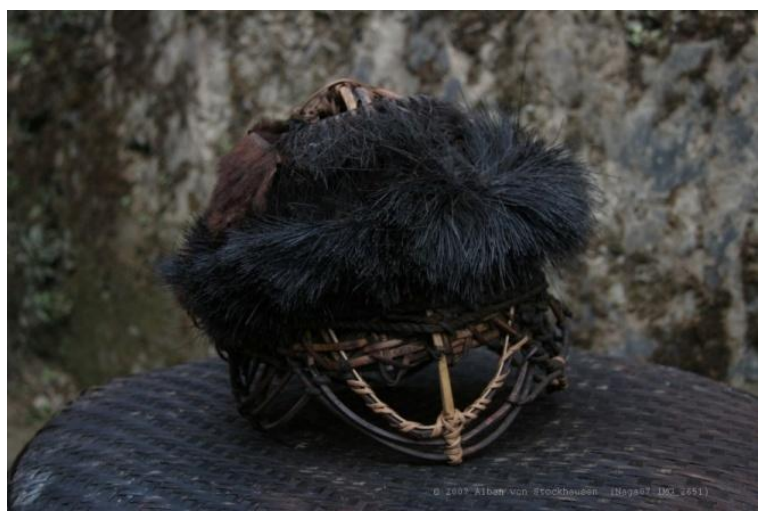

Fig. 8 a sturdy war helmet made of seasoned cane, strengthened by an addition of nettle fiber twisted into a stout cord and wound in a continuous spiral around the hat for extra protection. On the inside strips of nettle fiber cloth are sewn on to the frame acting as a cushion to the head and decorated with pig's bristles and bear's fur, Tuensang, 2007

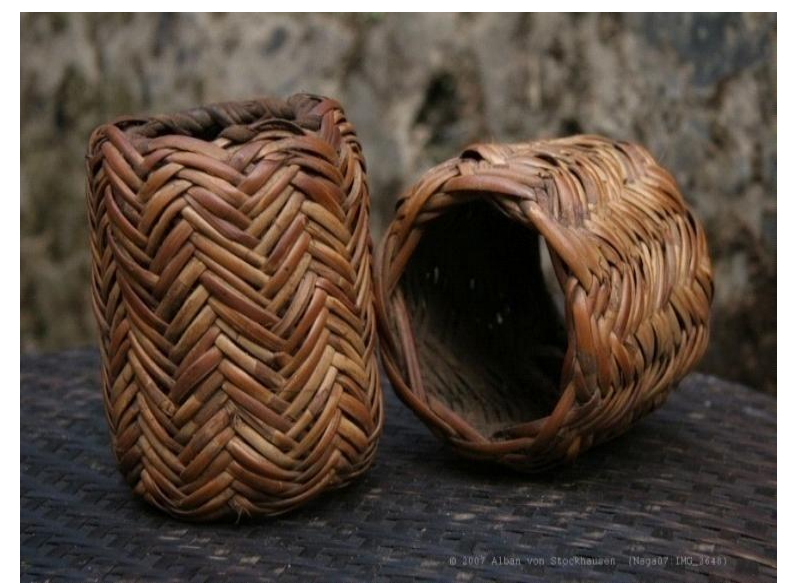

Fig.9 an armguard made of seasoned cane, Tuensang 2007

\section{X1. Tattooing}

Tattooing was confined to the northern and central Nagas such as the Chang, Sangtam, Ao, Phom, Yimchungrü, Khiamniungan and the Konyak. As with any other ornaments tattooing serves to make statements about membership of groups and status within groups (Jacobs 1990:112). Tattoos on arms and chest with human figures and various zigzag patterns are associated not only with headhunting but it also enabled a man to tell a friend from a foe, particularly when a number of villages had combined to attack another village.

The V-shaped tattoo with slight variations on the chest of Chang, Khiamniungan, Phom and Yimchungrü men are commonly known as a 'tiger chest' indicating that the wearer could "act like a tiger and 
kill his enemies" (Saul 2005:36). Both men and women tattoo among the Khiamniungan, Yimchungrü, Phom and the Chang but the Ao, Sangtam and some Tangkhul Nagas only tattoo their women.

Among the Chang Nagas, woman's facial tattoos represent her clan. For instance, The Ongh, Lomou, Honghang and Khangshou clan have identical forehead tattoo known as khüngbub which consist of a lozenge shape that had its sides extended at the top and bottom. The tattoo on the chin known as kaobüb differs from clan to clan. Ongh woman has three wavy horizontal lines on her chin whereas the Lomou has an X-shaped tattoo between two simple vertical lines. But both has the same chevron shape > to the corner of their mouth. Honghang woman chin tattoo is identical to the Lomou and Khangshou chin tattoo but the Khangshou chin tattoo is enclosed within a chevron > shape (Interview with Bümütyano, Tuensang village, 2010).

\section{X11. House decorations}

Certain decorations and additions to Naga houses advertise the wealth of the owner. One of these decorations among northern and central region is the actual buffalo and mithun skulls adorning the front porch of the house and the vertical tassels of thatching grass hanging down at the front gable and bamboo pole projecting from the roof with tassels. Among the Phom Nagas, the man who has performed the fourth series in the feasts of merit can put up an X-shaped projection of split bamboo along the ridge of his house roof and with the performance of the last feast known a hamniman he can decorate his field house with woodcarvings.

In some Khiamniungan villages such as Pathso, Noklak, Pusho and Wei and in Yimchungrü villages such as Mimi in Longpfuri area, feasts givers roofed their houses with slates. The Lothas and the Rengmas also erect stone monoliths to commemorate the giving of feasts. The Tangkhul Naga donor of feasts presents the best example of decorated individual house. The door and the walls of the house are elaborately carved in low relief of conventionalized mithun heads and life size human figures and rows of human heads in high relief. At times circles alternating with what looks like an enemy's teeth stand between the stylized mithun heads on the panel of the house. Similarly the Angami feasts giver decorate the front of his house with painted or carved representations of man and woman, mithuns, human heads, hornbill features, spears, daos, shield and concentric circles.

The decorations and woodcarvings in private houses were "a symbol of prestige, honour and influence. By conferring high social status on such men the society was providing incentives and motivations to the others to become powerful and wealthy, Such motivations and recognition was essential for the existence of the tribes" (Lotha 1998:21). Decorations on the morung also reflected the fearlessness, bravery and wealth of the men in the village. For example, in Tuensang village, the cane and bamboo basket balls hanging from the eaves of the morung symbolized enemies' heads, while the V- shaped projections of bamboo splints along the ridges of the morung roofs and the three wooden imitations of hornbill feathers in front of the morung symbolizes the wealth of the morung members, and the grass fringes referred to as morung necklace and a grass tassel called morung bell suspended on cane ropes hanging from the middle of the gable signifies the youthfulness, beauty and virility of the morung members.

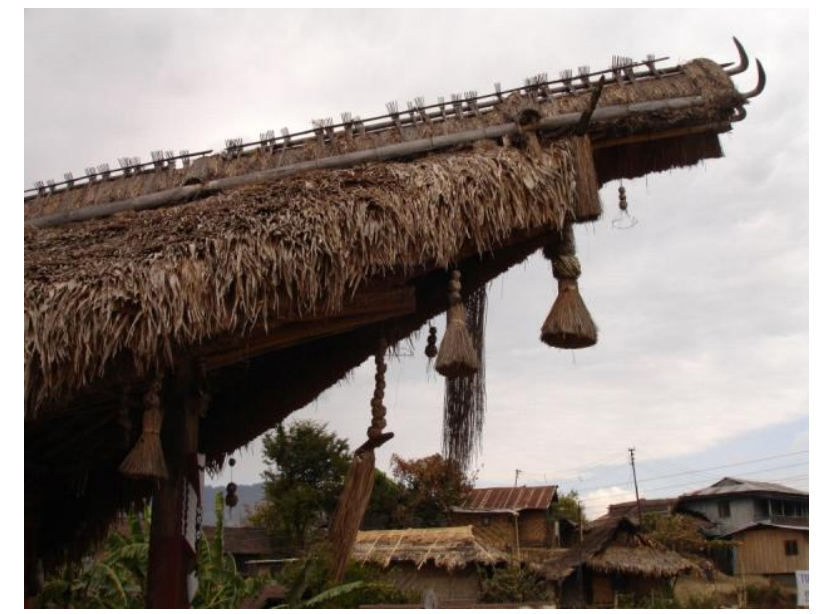

Fig.10 Decorations on the morung reflects the fearlessness, bravery and wealth of the men in the village,

Tuensang village, 2007

\section{X111. Conclusion}

Much of Naga art consist of perishable material and in the past, one of the main concerns for every Naga village was the protection against frequent enemy attacks and the spread of disastrous fires and the rigid observations of the rituals and taboos surrounding certain arts, which discouraged the artists from devoting 
much of their time to produce lasting art forms. In spite of the difficulties and insecurities of life, Nagas' artistic creativity flourished.

Contemporary life styles have brought changes to all Naga villages. Some Naga artisans has taken up jobs working as carpenters, schoolteachers, entrepreneurs, manual laborers such as mechanics and construction workers. Naga artisans have adopted to meet the demands of modern life and continue to be tough and flexible holding the fabric of Naga culture. Providing not only technical and financial assistance but also teaching them the awareness and appreciation of the uniqueness of their art, will build up their self-esteem, and also improve their quality of life and generate self employment and independence. In order for Naga art to persist, a mere nostalgic renewal of traditional skills and knowledge of the arts will not ensure a vibrant future. Introduction of traditional skills and knowledge such as woodcarving, textile and basketweaving, metalwork, pottery along with other cultural expressions through fusion music, theater, drama, literature, paintings, dances, film making to future generations such as schools and colleges will generate interest in students who are inclined towards the art

\section{References}

[1]. Lotha, Abraham, History of Naga Anthropology (1832-1947) Chumpo Museum Publication. History of Naga Anthropology 18321947 (2007)

[2]. Pemperon, Robert Boileau, the Eastern Frontier of Nagaland. Calcutta: Baptist Mission Press, 1835

[3]. Hodson, Thomas Callan, the Naga Tribes of Manipur. London: Macmillan \& Co. Ltd, 1911

[4]. Hutton, John Henry, the Meaning and Method of the Erection of Monoliths by the Naga Tribes. The Journal of the Royal Anthropological Institute of Great Britain and Ireland, 52:55-70. 1922

[5]. Hutton, John Henry, the Significance of Head-Hunting in Assam. The Journal of the Royal Anthropological Institute of Great Britain and Ireland, 58 (2): 399-408. 1928

[6]. Balfour. Henry, the Evolution of Decorative Art: An Essay upon Its Origin and Development as Illustrated by the Art of Modern Races of Mankind. London: Rivington, Percival and Co. 1893a

[7]. Fürer, Haimendorf, C. Von, the Morung System of the Konyak Nagas. The Journal of the Royal Anthropological Institute, 68: 349378. 1938

[8]. Fürer, Haimendorf, C. Von, Social and Cultural Change among the Konyak Nagas. The Highlander, 1 (1):3-12. Kohima: Department of Art and Culture. 1973

[9]. Hodson, T.C, Head-hunting among the Hill Tribes of Assam. Folklore, 20 (2):132-143. 1909

[10]. Lotha, Abraham, Naga Warfare (unpublished manuscripts) 1998

[11]. Lotha, Abraham, Understanding Naga Woodcarving (unpublished manuscripts) 1998

[12]. Lotha, Abraham, Naga Woodcarving Heritage: Carving the Present and the Future. Paper presented at 'This Sacred Land': An exhibition to promote Naga Art. The Gallery, Majestic Building, Kohima, April 12-14. 2007

[13]. Mills, James Philip, Certain Aspects of Naga Culture. The Journal of the Royal Anthropological Institute of Great Britain and Ireland, 56: 27-36. 1926

[14]. Mills, James Philip, the Effects of Rituals upon Industries and Arts in the Naga Hills. Man, 35:132-135. 1935

[15]. Allen, B.C, Gazetteers of Naga Hills and Manipur, Assam Secretariat Press, Shillong, Vol. 1X. 1907

[16]. Ham, Peter van and Jamie D. Saul, Expedition Naga. Dairies from the Hills in Northeast India 1921-1937, 2002-2006. Woodbridge: Antique Collectors Club, 2008

[17]. Needham, Rodney, Skulls and Casualty, Man, New Series, 11 (1):71-88. 1976

[18]. Sanyu, Visier, a Reflection on Naga Historical Research. in Vashum R (ed.) Naga Journal of Indigenous Affairs. Vol.1. New Delhi. Pp.48-51.2002

[19]. Spielmann, Katherine A, Feasting, Craft Specialization, and the Ritual Mode of Production in Small-Scale Societies. American Anthropologist 104:195-207. 2002

[20]. Steen, Charlie R, Material Culture of the Langsing Naga, Northern Burma. Southwestern Journal of Anthropology, 4 (3): $263-298$. 1948

[21]. Aier, Anungla, Cultural Change among the Nagas: Festival and Dress. Neivetso Venuh (ed): Naga society: Continuity and Change. Delhi: Shipra Publications. PP.49-59. 2004

[22]. Aier, Anungla, Agricultural Cycle Associated Rituals and the Role of Women. In Richard \&Vibha Joshi (eds). Naga - A Forgotten Mountain Region Rediscovered. Basel: Christoph Merian Verlag and Museum der Kulturen. PP.122-129. 2008

[23]. Ao, Alemchiba M, Arts and Crafts of Nagaland, Kohima, Nagaland: Naga Institute of Culture. 1968

[24]. Arya, Aditya \& Vibha Joshi, The land of the Nagas. Ahmedabad: Mapin Publishing Pvt Ltd. 2004

[25]. Hutton, John Henry, The Mixed Culture of the Naga Tribes. The Journal of the Royal Anthropological Institute of Great Britain and Ireland, 95 (1):16-43. 1965

[26]. Channa, Subhadra Mitra. (ed), Nagaland, a Contemporary Ethnography. New Delhi: Cosmo Publications. 1992

[27]. Chasie, Charles, Administrative and Social Factors: The Change in Naga Society. Neivetso Venuh (ed.): Naga Society Continuity and Change. Delhi: Shipra Publications. Pp.129-139. 2004

[28]. Elwin, Verrier, the Art of the North-East Frontier of India. Shillong. North-East Frontier Agency. 1959

[29]. Elwin, Verrier, the Nagas in the Nineteenth Century. Bombay: Oxford University Press. 1969

[30]. Fürer, Haimendorf, C. Von, Return to the Naked Nagas. London: John Murray. 1976 Ganguli, Milada, A pilgrimage to the Nagas. New Delhi: Oxford \& IBH Publishing Co. 1984

[31]. Ganguli, Milada, Naga Art. New Delhi: Oxford and IBH Publishing Co. 1993

[32]. Horam, M, Social and Cultural Life of Nagas .B.R. Publishing Corporation Delhi: 1997

[33]. Horam, M, Nagas Old Ways and New Trends. New Delhi: Cosmo Publications. 1988

[34]. Hutton, John Henry, the Angami Nagas. London: Macmillan and Co. Ltd. 1921a

[35]. Hutton, John Henry, the Sema Nagas: London: Macmillan and Co. Ltd. 1921b

[36]. Jacobs, Julian, the Nagas: Hill Peoples of North East India. London: Thames and Hudson. 1990

[37]. Joshi, Vibha, Feasts and Festivals. In Richard \&Vibha Joshi (eds). Naga - A Forgotten Mountain Region Rediscovered. Basel: Christoph Merian Verlag and Museum der Kulturen, pp.148-151, 2008 
[38]. Joshi, Vibha, Angami Village Gates kharu. In Richard \&Vibha Joshi (eds). Naga - A Forgotten Mountain Region Rediscovered. Basel: Christoph Merian Verlag and Museum der Kulturen, pp. 61-63. 2008

[39]. Lanunungsang, Working System of the Ariju in Traditional Ao Society: A Socio-cultural Institution. Neivetso Venuh (ed.): Naga Society Continuity and Change. Delhi: Shipra Publications. Pp.61-86, 2004

[40]. Lintner, B, Land of Jade. A Journey from India through Northern Burma to China. $2^{\text {nd }}$ revised edition. Bangkok: White Orchid Press. 1996

[41]. Mills, James Philip, the Lotha Nagas. London: Macmillan \& Co. Ltd. 1922

[42]. Mills, James Philip, the Ao Nagas. London: Macmillan \& Co. Ltd. 1926

[43]. Mills, James Philip, the Rengma Nagas. London: Macmillan \& Co. Ltd. 1937

[44]. Mongro, Kajen (ed. by Lanu Ao), Naga Cultural Attires and Musical Instruments. New Delhi: Concept. 1999

[45]. Oppitz, Michael, Thomas Kaiser, Alban von Stockhausen, Rebekka Sutter, and Marion WettsteinNaga Identities: Changing Local Cultures in the Northeast of India. Snoeck Publishers, Gent, 2008

[46]. Price, Sally, Primitive Art in Civilized Places. Chicago: University of Chicago Press. 2001

[47]. Renchen Women Welfare Society, Lotha Naga: Textiles and Patterns (1914-1947), Wokha, Nagaland. 2010

[48]. Rosaldo, Reneto, Ilongot Headhunting (1883-1974). Stanford University Press, 1990

[49]. Saul, Jamie, the Naga of Burma: Their Festivals, Customs and way of Life. Thailand: Orchid Press. 2007

[50]. Shimray, R.R, Origin and Culture of Nagas. New Delhi: Pamleiphi Shimray. 1985

[51]. Stirn, Aglaja \& Peter Van Ham, the Hidden World of the Naga: Living Traditions in Northeast India and Burma. München, Berlin, London, New York: Prestel. 2003

\section{Picture Credits}

Alban von Stockhausen, Zürich, photographs: Fig.5, Fig. 8, Fig.9

Chingmak Lomou, Bangalore, photographs: Fig.10

Iris Odyuo, Tuensang, photographs: Fig.1, Fig.3

Museum für Völkerkunde Wien, Photograph Collections: 126376 (Fig.2), VO_181966 (Fig.4), 126664 (Fig.6), 126531 (Fig.7), 